\title{
A Learning Trajectory Study on How the Concept of Variable Is Constructed by Students
}

\author{
M. Cagri Gurbuz ${ }^{1, *} \&$ M. Emin Ozdemir ${ }^{1}$ \\ ${ }^{1}$ Faculity of Education, Bursa Uludag University, Bursa, Turkey \\ *Correspondence: Faculity of Education, Bursa Uludag University, Bursa, Turkey. Tel: 90-224-294-2593. E-mail: \\ mcgurbuz@uludag.edu.tr
}

Received: January 17, 2020

Accepted: February 17, $2020 \quad$ Online Published: February 20, 2020

doi:10.5430/wje.v10n1p134

URL: https://doi.org/10.5430/wje.v10n1p134

\begin{abstract}
The aim of this study was to examine 6th-grade students' mathematical abstraction processes related to the concept of variable by using the teaching experiment method and to reveal their learning trajectories in the context of the $\mathrm{RBC}+\mathrm{C}$ model. A teaching experiment was administered to a class of 29 middle school students for 3 weeks. Observations, interviews, and the Diagnostic Algebra Test were used as data collection instruments to reveal the students' abstraction processes and determine their learning trajectories. Qualitative data were analyzed through content analysis, and qualitative data were analyzed through paired-samples t-test. The learning trajectories showed that only the students with good performance exhibited the "construction" action when using "variables as changing quantities," but the "building-with" action when using the other types of variables. Mediocre students, however, needed teacher support to perform the building-with action in the process of abstraction of variables. The students' written tips such as drawing arrows or deleting the variable show that it helps to learn how to replace a variable with a known value. This study shows that the development of thought on variables is embedded in the progression of the concept of variable as a changing quantity. Similar studies can be conducted for the use of variables in equations and for the understanding and interpretation of variables when solving equations.
\end{abstract}

Keywords: mathematical abstraction, learning trajectory, variable, teaching experiment

\section{Introduction}

A result-oriented instruction can adversely affect the learning process of students in mathematics education. For this reason, it is more important how students learn rather than what they learn. If how knowledge is constructed in the student's mind is known, teachers may be more likely to intervene effectively in the learning process.

Research shows that students have difficulty understanding algebra concepts (Brizuela, et. al., 2000; Dede \& Argün, 2003; Ersoy \& Erbaş, 1998; Kieran, 1992; Linchevski \& Herscovics, 1996; MacGregor \& Stacey, 1993; Philips, 1999). One of the main reasons for these difficulties is the use of literal symbols in mathematics to have different meanings (Blanton et al., 2015; Çelik \& Güneş, 2013; Driscoll, 1999; Philipp, 1999; Schoenfeld \& Arcavi, 1988; Soylu, 2008). The results of research on the challenges faced by students in the algebra learning process can be grouped in two categories (Lins, 1992): (a) Algebra contains very general statements about the nature of mathematical activities, and apart from general intellectual developmental theories, it is not possible to clearly define algebraic thought, and (b) Most of the research on algebra learning is local, and the results of these studies mostly explain failures. Consequently, research on the learning and use of algebra does not produce profound and conclusive results. In this regard, it would be appropriate to offer a constructive framework for how students mentally construct knowledge in algebra.

It is quite difficult to observe the process of knowledge construction directly. In mathematics, abstraction is the process of revealing the essence of a concept, i.e., the process of constructing knowledge. Various theories have been proposed to examine the abstraction process. One of these theories is the $\mathrm{RBC}+\mathrm{C}$ abstraction theory, which examines the epistemic actions that students undergo in the process of solving contextual problems. Abstraction in the theory is defined as the process of construction of a new mathematical structure by vertically reorganizing pre-constructed mathematical knowledge (Hershkowitz, Schwarz, \& Dreyfus, 2001; 2009; 2015). Vertical mathematization means 
the depth of established connections and the integration of knowledge (Treffers, 1987). The theory is named after a combination of the first letters of the epistemic actions: recognition, building with, constructing, and consolidation. An epistemic action implies a specific type of mediation involving cognitive processes and mathematical concepts.

Recognizing (R): This action occurs when the student realizes that a certain structure exists in a given mathematical situation. Such structures may be something the student already knows.

Building-with (B): This action occurs when the student uses certain existing structural knowledge to create a solution to the problem. In a sense, the epistemic action of building-with is target-driven and may include the integration of existing knowledge (but it does not generate new knowledge).

Constructing (C): This action is a central epistemic action and is necessary for an abstraction to occur. A student must use a new mathematical structure to construct knowledge. In essence, "it implies the construction of innovation" (Hershkowitz et al., 2001). Constructing is a combination of previous structures through vertical mathematization.

Consolidation $(+\mathrm{C})$ : This is the student's finding a previously created mathematical structure familiar and his or her conscious reuse of the new structure (Dreyfus \& Tsamir, 2004).

The fact that the abstraction process can be monitored through these epistemic actions allows monitoring the mental development of a student and recognizing the difficulties he or she has experienced (Yeşildere İmre \& Türnüklü, 2016).

Research on how students construct knowledge conducted by math educators uses learning trajectories as an organized framework (Clements \& Sarama, 2004; Confrey et al., 2009; Simon, 1995). Students go through natural developmental progressions when learning mathematics, and they learn mathematical ideas and skills in their own way (Clements \& Sarama, 2010). Effective and enriched learning environments can be created when such developmental progressions are understood and mathematical activities based on them are sequentially organized. Such developmental progressions are the main component of a learning trajectory. Research shows that a learning trajectory has three parts by nature (Clements \& Sarama, 2010): (a) a mathematical goal, (b) developmental progressions that students develop to achieve this goal, and (c) a series of instructional activities or tasks that correspond to each of the levels of thought in this trajectory that help students develop higher levels of thinking. Let us briefly describe each of these parts:

(a) A learning trajectory starts with a mathematical goal. Each goal is a set of concepts and skills that are mathematically consistent and will generate future learning through students' thinking. For instance, algebraic thinking involves recognizing patterns, analyzing them, examining relationships, representing them, and making generalizations.

(b) Developmental progressions refer to a typical path that children follow in developing understanding and skills on a mathematical subject. Each developmental progression is more sophisticated than the preceding one, which allows mastering the mathematical goal. For example, even before learning algebra, students have certain mathematical competencies related to patterns in geometric terms (such as finding the amount of increase in patterns).

(c) The third part of a learning trajectory consists of a series of learning activities that correspond to each level of thinking in developmental progressions. These activities are designed to help children learn the ideas and skills needed to achieve their corresponding developmental progressions. This means that teachers can use these tasks to enhance children's mastery from one level to another.

In this study, a learning trajectory was employed as a basis for understanding how students virtually constructed algebraic relationships in variables and for systematically characterizing advances in their thinking. In this study, the learning trajectory was shaped based on the students' and the teacher's interpretations of the concept of variable. In this respect, the learning trajectory had practical outcomes for the students' learning and mental development. A hypothetical learning trajectory was designed to make the students' abstract thoughts more visible and understandable. In this process, it was desired to eliminate the handicaps of the students who encountered the concept of variable for the first time. Knowing that students face many challenges, it was aimed in this study to reveal how they understand algebra (Banerjee \& Subramaniam, 2011; Drijvers, Goddijn \& Kindt, 2011) and to develop an instructional unit that would help them in the learning process.

In this context, the aim of this study was to examine 6th-grade middle school students' mathematical abstraction processes related to the concept of variable and to reveal a learning trajectory in the context of the $\mathrm{RBC}+\mathrm{C}$ model. To that end, "what is 6th-grade students' learning trajectory for the concept of variable?" was defined as the problem statement. 


\section{Method}

This study involved the teaching experiment method (Simon \& Tzur, 2004), which is a useful method to determine a learning trajectory for learning variables. Teaching experiments make important contributions to the study of the development of mathematical concepts in students (Steffe \& Thompson, 2000). In the present study, the teaching experiment consisted of three phases: preparation, implementation, and evaluation (Steffe \& Thompson, 2000), which are detailed in the Learning Process heading below.

\subsection{Learning Process}

The teaching experiment lasted for three weeks and a total of ten course-hours in a cyclical process. During the preparation phase, the types of use of variables were determined. Four types of variable use were selected as the mathematical goals in the study. The mathematical activities determined to achieve these goals were discussed with the teacher and were adapted to the classroom environment. The Chelsea Diagnostic Test for Algebra (CDTA) was administered to determine the students' prior knowledge and thus their achievement levels. The levels of the participant students set the difficulty level of the mathematical activities. During the implementation phase, the mathematical activities developed for the learning trajectory were carried out. Issues that needed to be corrected in the mathematical activities were determined. During the evaluation phase, the students' developmental progressions were examined as an outcome of the mathematical activities. The students were asked questions through individual interviews about their mental knowledge construction/abstraction about the mathematical goals.

\subsection{Preparation}

Table 1. Hypothetical Learning Trajectory for Students

\begin{tabular}{|c|c|c|c|c|}
\hline Goal & Hypothesis & & Evaluation & \\
\hline $\begin{array}{l}\text { Mathematical } \\
\text { Goal }\end{array}$ & $\begin{array}{l}\text { Mistakes Expected } \\
\text { to Happen During } \\
\text { the Course }\end{array}$ & Activity (A) & Developmental Progressions & Evaluation \\
\hline $\begin{array}{l}\text { Variable as a } \\
\text { label }\end{array}$ & $\begin{array}{l}\text { Incorrect } \\
\text { representation in } \\
\text { algebraic use }\end{array}$ & $\begin{array}{l}\text { (A1) Algebraic } \\
\text { representation of } \\
\text { the number of fish }\end{array}$ & $\begin{array}{l}\text { Students are expected to } \\
\text { develop skills to understand } \\
\text { the context of the problem } \\
\text { and create representations. }\end{array}$ & $\begin{array}{l}\text { They gain } \\
\text { experience in a } \\
\text { number of aspects } \\
\text { of mathematical } \\
\text { research: check for } \\
\text { special situations, } \\
\text { and explain a } \\
\text { generalization }\end{array}$ \\
\hline $\begin{array}{l}\text { Variable as a } \\
\text { Changing } \\
\text { Quantity }\end{array}$ & $\begin{array}{l}\text { Incorrectly } \\
\text { generalizing the rule } \\
\text { of a pattern } \\
\text { algebraically }\end{array}$ & $\begin{array}{l}\text { (A2) Hexagonal } \\
\text { tables }\end{array}$ & $\begin{array}{l}\text { They are expected to be able } \\
\text { to explain a contextual } \\
\text { arithmetic model } \\
\text { algebraically. }\end{array}$ & $\begin{array}{l}\text { Show algebraically } \\
\text { the pattern they } \\
\text { explained } \\
\text { arithmetically }\end{array}$ \\
\hline $\begin{array}{l}\text { Variable as a } \\
\text { Known Value }\end{array}$ & $\begin{array}{l}\text { Inability to assign } \\
\text { numerical values to } \\
\text { a variable }\end{array}$ & $\begin{array}{l}\text { (A3) Cost } \\
\text { calculation }\end{array}$ & $\begin{array}{l}\text { They are expected to create } \\
\text { an algebraic model that } \\
\text { always works. }\end{array}$ & $\begin{array}{l}\text { Understand that a } \\
\text { variable is a value } \\
\text { that varies and can } \\
\text { present an algebraic } \\
\text { model }\end{array}$ \\
\hline $\begin{array}{l}\text { Variable as an } \\
\text { Unknown Value }\end{array}$ & $\begin{array}{l}\text { Inability to do four } \\
\text { basic arithmetic } \\
\text { operations with } \\
\text { variables }\end{array}$ & $\begin{array}{l}\text { (A4) Think of a } \\
\text { number }\end{array}$ & $\begin{array}{l}\text { They are expected to use } \\
\text { variables in four basic } \\
\text { arithmetic operations. }\end{array}$ & $\begin{array}{l}\text { Can use and } \\
\text { manipulate } \\
\text { variables in four } \\
\text { basic arithmetic } \\
\text { operations }\end{array}$ \\
\hline
\end{tabular}

A learning trajectory should theoretically be target-driven. In order to achieve such a goal, the trajectory should include teaching activities, and it should be reorganized by testing a hypothetical learning trajectory. The concept of variable in this study was based on "four different uses of literal symbols" as summarized by Blanton et al. (2015) from the literature. The curriculum (MEB, 2017) played a role when determining the mathematical goals. The first 
mathematical goal was about how the students would use literal expressions - which the students were familiar with from arithmetic operations - in algebraic thinking. The second goal was to find the rule of a pattern and to express the pattern in letters. The third goal was to be able write an algebraic expression and replace a variable with a number. The last goal was to determine the concept of variable as an unknown and to be able to perform operations with algebraic expressions. Table 1 shows the functional scheme of the prepared hypothetical learning trajectory and the related issues that came up during the course.

In this study, the teacher who taught the class was pursuing his doctoral education in the field of mathematics education. The reason why he was chosen was the fact that he had a close work relationship with the researcher and that he was eager to learn new techniques of algebra teaching. Regular interviews were conducted with the teacher before and after the weekly scheduled lessons. After the hypothetical learning trajectory was created, the learning trajectory was determined based on the interviews with the teacher.

\subsection{Participants}

The participants were selected from among 6th-grade students at a public middle school in Bursa in the 2016-2017 academic year. The sample was selected according to the criterion sampling method, and the following were determined as the criteria: (a) the students had to enroll in classes taught by the same mathematics teacher, and (b) they had to be at the 6th grade level, the curriculum of which included the concept of variable. A total of 29 students who met the criteria were identified as participants. The participants to be interviewed were determined using the purposeful random sampling method, which allows randomly determined participants to be classified for the purpose of a study (Marshall \& Rossman, 2014). In order to see the differences according to mathematics achievement levels, a student was selected randomly from each of the good, intermediate and mediocre categories. Individual interviews were conducted with these three students. CDTA, which is explained below, and the teachers' opinions were effective in determining these categories.

\subsection{Data Collection Instruments}

Along with the description of subjects, give the mended size of the sample and the number of individuals meant to be in each condition if separate conditions were used. State whether the achieved sample differed in known ways from the target population. Conclusions and interpretations should not go beyond what the sample would warrant.

\subsubsection{Interview}

Semi-structured individual interviews were conducted to understand how the students constructed the concept of variable in their minds. The stages proposed by Yıldırım and Şimşek (2011) were taken into consideration during the preparation of an Individual Interview Form. These interviews were conducted after each instructional activity. The interview questions were designed to attract the attention of the students and to reveal the mathematical abstraction processes of the students in accordance with the research problem, in addition to having the features explained above. During the individual interviews, the researcher asked questions such as "Can you explain aloud what you're doing right now?", "How did you decide to resolve it this way?", and "Why?", which could help the researcher to examine the student's answers in depth in order to reveal the epistemic actions of the students (Hunting, 1997).

\subsubsection{Chelsea Diagnostic Test for Algebra (CDTA)}

The Chelsea Diagnostic Test for Algebra developed by Küchemann et al. $(1985 ; 1998)$ was administered to determine the students' level of prior knowledge on the subject and to reveal the students' mistakes. Moreover, the contribution of the trajectories to the mathematical understanding of the students was investigated with the test. The test consisted of 22 questions. The students answered the questions in about 50 minutes. CDTA was translated and adapted into Turkish by Çıkla (2004) (its KR-20 value is .93). The reliability of the test used in this study was calculated by using the KR-20 formula and was .88 .

\subsubsection{Observation}

Observation as one of the techniques of data collection in qualitative research is a good way to investigate behaviors in detail in a certain environment, in their natural environment (Glesne, 2013). Semi-structured observation form was established by taking expert opinions to examine the learning trajectory during the implementation process of the study. The researcher assumed a participant observer role and kept field notes about the teaching experiment in the classroom environment (Maxwell, 2005).

\subsection{Data Analysis}

In this study, observations and field notes were utilized to identify the students' developmental progressions, instructional goals and mistakes. The observation notes and the individual interviews with the students were analyzed 
by using the content analysis method. Content analysis requires an in-depth analysis of data. Therefore, by using this analysis, data are defined, and the facts that may be hidden in the data are presented within the framework of concepts and themes specified within a study (Yıldırım \& Şimşek, 2008). In the present study, the $\mathrm{RBC}+\mathrm{C}$ abstraction model was used in two processes: First, to determine the phases of developmental progressions when creating the learning trajectory, and second, to systematically organize analysis of the abstraction process of the concept and to cognitively interpret the expressions as a result of the interviews with the students. In the second phase, audio recordings recorded during the interviews were transcribed. Pseudo names were assigned to the students in the transcripts of the interviews. In the findings, students with good, moderate and mediocre performance were referred to as the abbreviations $\mathrm{H}, \mathrm{M}$ and $\mathrm{G}$, respectively. As the $\mathrm{RBC}+\mathrm{C}$ Abstraction Model was used as a tool for observing epistemic actions, the data were organized into themes and presented according to this framework. The transcripts were analyzed according to this framework. During the data analysis, a table (Table 2) was used to determine the phases of epistemic actions represented by the students' statements.

Table 2. Keywords for Determining Epistemic Actions

\begin{tabular}{lll}
\hline Recognizing & Building-with & Construction \\
\hline Awareness & Problem solving & Coming up with new structures \\
Knowing the characteristics of the & In-depth thinking & Reasoning \\
variable & Understanding or explaining a situation & Reflection \\
Giving an example & Making assumptions & Developing a mathematical \\
& Associating with & language \\
\hline
\end{tabular}

A 3-level scoring scale was used to evaluate the CDTA: (0 points: No skills were used; 1 point: A skill was used, but the correct solution could not be achieved; 2 points: A skill was used and the problem was solved). To determine if there was any significant difference between the students' responses to the achievement test, the data were edited in the Microsoft Excel program, transferred to the SPSS 25.0 program and analyzed there. During the analysis, total scores were obtained, and whether they were distributed normally was checked through Shapiro-Wilk Tests (Can, 2013, pp. 89). In the results of the Shapiro-Wilk Tests, $p>.05$ was accepted as normal distribution (Büyüköztürk, 2011, pp. 42). Paired-samples t tests, a type of parametric tests, were carried out because the test results showed normal distribution.

Help was received from an expert and a second coder (teacher) for the reliability of data analysis in the study (Miles \& Huberman, 1994). The second coder was informed in the process about the aims in the study, the basic characteristics of the concept of measurement and the analysis of data. Kendall's coefficient of agreement between the researcher and the second coder was above .85, indicating a high level of agreement between the coders (Abdi, 2007). An attempt was made to achieve the objectivity/confirmability of the study (Miles \& Huberman, 1994) by presenting the method of the study and the research process in accordance with the actual order of conduct, and by presenting them in a clear manner that would allow reanalyzing the data. For transferability, which ensures the validity of the study (Miles \& Huberman, 1994), detailed information about the characteristics of the participating students, the teaching environment and the teacher are provided.

\section{Results}

The findings about the implementation phase of the learning trajectory are presented in the tables below. The first column of these tables contains the mathematical goal. In the second column, the developmental progressions of the students are seen according to the analysis of the teaching activities. Based on the steps of the $\mathrm{RBC}+\mathrm{C}$ abstraction model, the developmental progressions of the students were defined hierarchically. The third column summarizes the teaching activities developed within the scope of the learning trajectory. Moreover, the table shows sample questions about the mathematical goal from the CDTA questions and student evaluations. Finally, student mistakes and explanations are included according to the results of the analysis. Immediately after the tables, evidence was presented about the students' level of achievement based on the teaching activity. Finally, evidence for the abstraction processes, which was obtained from the interviews, was shared.

Given the mathematical careers of the students prior to learning algebra, they first learn to use letters to label certain known quantities or to symbolize a certain quantity. For example, in their prior mathematical careers, they use the phrase " 4 a to represent 4 apples." The process of teaching a variable as a label, which is the first mathematical goal, is shown in Table 3 below. The mathematical goal as an instructional objective is associated with writing an algebraic 
expression that is appropriate for a life situation.

Table 3. The Teaching Process of a Variable as Label

\begin{tabular}{|c|c|c|}
\hline Goals & Developmental Progressions & Instructional task \\
\hline $\begin{array}{l}\text { Variable as } \\
\text { label }\end{array}$ & $\begin{array}{l}\text { R: They were able to use abbreviations when thinking } \\
\text { arithmetically. They described Suleyman as S. } \\
\text { Suleyman was written as S. } \\
\text { Recep = Solomon }+7 \\
\mathrm{~S}+7 \\
\text { B: They wrote an algebraic expression based on the } \\
\text { verbal expression. They showed the number of fish } \\
\text { Recep has as "s }+7 \text { " and then " } \mathrm{x}+7 \text { ". }\end{array}$ & $\begin{array}{l}\text { A1: Question: Recep has seven more fish than } \\
\text { Suleyman. Find the numbers of fish they both have. } \\
\text { The students were then asked to abbreviate the names } \\
\text { of Suleyman and Recep as S and R, respectively, to } \\
\text { show them in an algebraic expression, and to sum } \\
\text { similar terms. It was stated that different terms would } \\
\text { not be summed up. They were asked to write a verbal } \\
\text { situation as an algebraic expression. } \\
\text { The activity continued with similar questions. } \\
\text { A football is covered by } 16 \text { hexagonal pieces of } \\
\text { leather. Add } 4 \text { more hexagonal pieces and show the } \\
\text { final status. }\end{array}$ \\
\hline CDTA & $\begin{array}{l}\text { GOOD and MODERATE: As expected, they summed } \\
\text { up similar terms, and they were also able to show an } \\
\text { expression with two different letters as } 3 a+5 b \text {. } \\
\text { MEDIOCRE: They wrote } 7 \mathrm{ab} \text {, or } 7 \mathrm{a}+\mathrm{b} \text {, ignoring the } \\
\text { variables. }\end{array}$ & $\begin{array}{l}\text { Write the expression " } 2 \mathbf{a}+\mathbf{5 b}+\mathbf{a} \text { " in the simplest } \\
\text { way possible: } \\
\text { The students needed to sum up similar terms in order } \\
\text { to give the correct answer. }\end{array}$ \\
\hline $\begin{array}{l}\text { Student } \\
\text { Mistakes }\end{array}$ & $\begin{array}{l}3 \text { apples }+4 \text { apples }+7 \text { bananas }=14 \mathrm{f} \text {. } \\
\mathrm{f}=\text { fruit }\end{array}$ & $\begin{array}{l}\text { This means that the students labeled objects whose } \\
\text { variables were different. }\end{array}$ \\
\hline
\end{tabular}

The purpose of using variables is to label objects (colors) or groups (certain shapes). For instance, 7r means "7 reds". In this case, the variable " $r$ " is a label for the color red. In another activity, the students wrote "h" to indicate that a football is made up of 20 hexagons and to label and shorten the word hexagon.

C: $16+4$ equals to 20 .

Teacher (T): 20 what?

A: $20 \mathrm{~h}$.

$\mathrm{T}$ : What does it represent? What does " $\mathrm{h}$ " mean?

A: Hexagon.

It is understood from the classroom environment and from the studies of the students that in the use of variables as labels, the students understood that an expression was the sum of similar and different terms and saw an algebraic expression as the act of finding the total amount. 


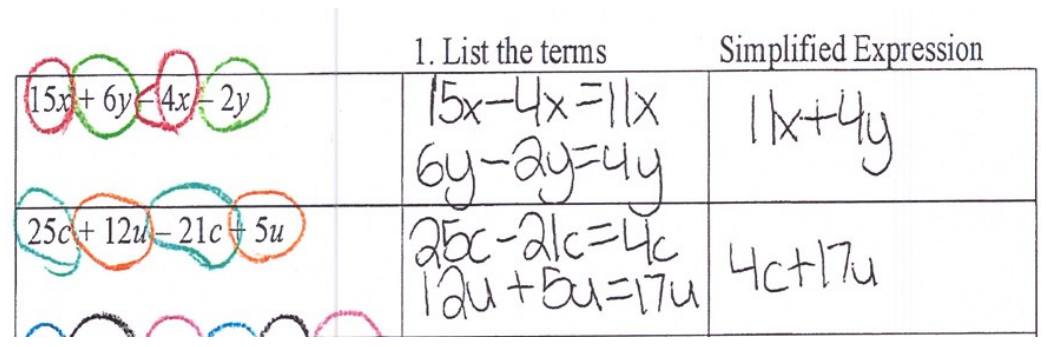

Figure 1. An Example of the Use of Variable as a Label

In Figure 1, examples from good students' notebooks are presented with regard to the activities held in the classroom. In these examples, the students were able to perform operations with terms similar to variables as labels. When the students' notebooks were examined, it was seen that approximately $62 \%(\mathrm{n}=18)$ were able to write expressions by simplifying them. This is an indication that they began to interpret algebraically the objects they had defined arithmetically.

In Table 4, the second mathematical goal as an instructional gain is related to understanding the amount of increase in a pattern and showing the rule of the pattern as an algebraic expression.

Table 4. The Teaching Process of a Variable as a Changing Quantity

\begin{tabular}{|c|c|c|}
\hline Goals & Development Progressions & Instructional task \\
\hline \multirow[t]{3}{*}{$\begin{array}{l}\text { Variable as } \\
\text { changing } \\
\text { quantity }\end{array}$} & $\begin{array}{l}\text { R: They tried to understand the change in the } \\
\text { number of chairs for each step. In the first step, } \\
\text { they found that six chairs could be placed around } \\
\text { a hexagon. (visual representation) }\end{array}$ & $\begin{array}{l}\text { A2: } 6 \text { chairs can be placed around a hexagonal table. Find } \\
\text { out how many chairs can be placed when the hexagonal } \\
\text { tables are placed side by side. }\end{array}$ \\
\hline & $\begin{array}{l}\text { B: They found that for } \mathrm{n}=2 \text { and } \mathrm{n}=3 \text {, the } \\
\text { increase in the number of chairs was } 4 \text {. They } \\
\text { understood that the increase was the same at every } \\
\text { step. } \\
\text { They showed the increase arithmetically based on } \\
\text { the number of chairs in the first step. } 6+4+4 \\
\text { (arithmetic representation) }\end{array}$ & $\begin{array}{l}\text { The procedures that the students were expected to carry } \\
\text { out for A2: } \\
\text { (a) Repeating the pattern } \\
\text { (b) Determining the amount of increase of the pattern } \\
\text { (c) Describing the rule of the pattern } \\
\text { (d) Confirming the rule of the pattern }\end{array}$ \\
\hline & $\begin{array}{l}\text { C: Thus, they switched between different } \\
\text { representations of the patterns. } \\
\text { They were able to write the rule of a pattern as an } \\
\text { algebraic expression. (algebraic representation) } \\
6+4 n\end{array}$ & $\begin{array}{l}\text { (e) Expressing the rule of the pattern algebraically } \\
\text { (f) Asking the students to share different representations } \\
\text { of the expression (Directing the students to find a more } \\
\text { efficient way to represent the same expression) }\end{array}$ \\
\hline CDTA & $\begin{array}{l}\text { GOOD: They were able to give a verbal } \\
\text { explanation as expected. They stated that it was } \\
\text { cost. } \\
\text { MEDIOCRE: They could not express that the } \\
\text { variable was changing in quantity. }\end{array}$ & $\begin{array}{l}\text { Question: A piece of toast is sold for " } \mathrm{t} \text { " Turkish Liras, } \\
\text { and a cup of ayran (a Turkish drink made of yogurt and } \\
\text { water) is sold for "a" Turkish Liras. If } 4 \text { pieces toasts and } \\
3 \text { cups of ayran are bought, what does } 4 \mathrm{t}+3 \text { a mean? }\end{array}$ \\
\hline $\begin{array}{l}\text { Student } \\
\text { Mistakes }\end{array}$ & $\begin{array}{l}\text { To model the cost of } 5 \text { different balls, the student } \\
\text { expressed the expression as } 5=\mathrm{d} \text {. }\end{array}$ & $\begin{array}{l}\text { This means that the student did not understand that the } \\
\text { cost was a varying amount and that the expression should } \\
\text { have been } 5 \mathrm{~d} \text {. }\end{array}$ \\
\hline
\end{tabular}


The table activity is visualized in Figure 2.

Number of tables $=1$

Number of chairs $=6$

Number of tables $=2$

Number of chairs $=10$

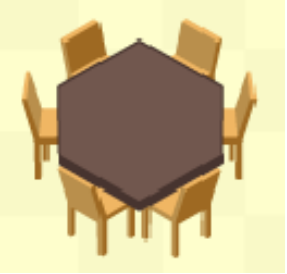

6 for $\mathrm{n}=1$

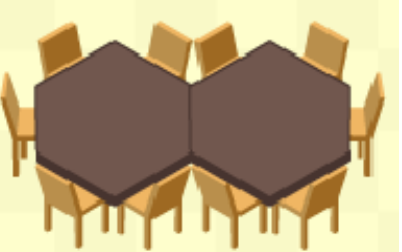

10 for $\mathrm{n}=2$

\section{Figure 2. The Visualization of the Table Activity}

The same question was discussed with the students during the individual interviews. The steps of the operations carried out by the mediocre students regarding the amount of increase in finding the rule of the pattern are seen below.

T: How did the number of chairs change when the 4 tables were placed side by side?

G: It's always gone up by 4 .

$11 \mathrm{G}$ : Yes, it is increasing in fours. The question is asking for the step 4.

12G: Then it will increase by 4 .

The student in the mediocre category performed this process more slowly and was able to define the amount of increase arithmetically. He also had difficulty in transitioning to an algebraic representation. At this stage, the encouraging role of the teacher is important. Below is a dialogue with the student who was in the good category about his calculating the change in the number of chairs and expressing the rule of the pattern when the 4 tables were placed side by side.

13H: Let's find the rule first.

14H: Okay. Then let's find the general rule first.

$15 \mathrm{H}$ : The amount of increase is $4.4 \mathrm{n}$ plus the amount in brackets...

16H: Subtract 4 from $10.4 \mathrm{n}+6$.

17H: Yes, $4 n+6$.

It is true to say that the students were able to define shortcuts and develop a new language of their own, so they carried out the epistemic action of "construction." The students in the classroom were particularly encouraged to use the language they had developed together when finding the general rule of the pattern. This method was determined by the students while solving an example when determining the general rule of the pattern in the course with the strategy of placing tables. And they continued to use it when they found that this method could be applied to other examples. The rule they found: It is [the amount of increase $\times \mathrm{n}+$ (the first step - the amount of increase)] if it is an increasing pattern and [the amount of decrease $\times \mathrm{n}+$ (the first step - the amount of decrease)] if it is a decreasing pattern. The rule that the students found is the verbal expression of the formula.

$$
\left[a_{n}=a_{1}+(n-1) \times r\right],
$$

Which is actually the expression of finding the general term of arithmetic sequences.

Variable as a known value is important for students to simultaneously understand a variable as a varying quantity. For instance, the students considered variables as varying quantities, and were able to immediately use the known values for the variables. First, the numerical value of the variable was tried to be used by finding the value of the desired term based on the previous trajectory. 
Table 5. The Teaching Process of a Variable as Known Value

\begin{tabular}{|c|c|c|}
\hline Goals & Development Progressions & Instructional task \\
\hline \multirow{6}{*}{$\begin{array}{l}\text { Variable as } \\
\text { known } \\
\text { value }\end{array}$} & \multirow{2}{*}{$\begin{array}{l}\text { R: Being able to change a given value } \\
\text { for the variable, }\end{array}$} & The lesson continued with A2. \\
\hline & & \multirow{2}{*}{$\begin{array}{l}\text { They were asked to perform the operation by writing the value given } \\
\text { for } n \text { in the algebraic expression " } 6+4 n \text { " in the corresponding } \\
\text { place. For } n=1,2,3\end{array}$} \\
\hline & \multirow{2}{*}{$\begin{array}{l}\text { They were able to calculate the results } \\
\text { of the first three steps in the algebraic } \\
\text { expression of the pattern for } n=1,2,3 \text {. }\end{array}$} & \\
\hline & & (g) Find the desired term using the rule of the pattern \\
\hline & $\begin{array}{l}\text { B: They understood that the coefficient } \\
\text { was multiplied by the value of the } \\
\text { variable. For example, they explained } \\
\text { that } 4 p \text { was } 4 \times p \text {. }\end{array}$ & $\begin{array}{l}\text { A3: Asking them to find the total cost of a product by using different } \\
\text { prices from different stores (Cost of } 4 \text { pens and } 1 \text { eraser: } 4 p+e) \text {. It } \\
\text { was intended to let them feel that calculations were needed here for } \\
\text { different values of the variable. }\end{array}$ \\
\hline & $\begin{array}{l}\text { C: It was understood that they used } \\
\text { symbols in a meaningful way to } \\
\text { evaluate an expression. }\end{array}$ & $\begin{array}{l}\text { When you place the value in its place in the algebraic expression, the } \\
\text { variable disappears. " } 4 \mathrm{p}+\mathrm{e}=4 \times 4+1=17 \text { " The desire was to help } \\
\text { them understand this. }\end{array}$ \\
\hline \multirow[t]{2}{*}{ CDTA } & $\begin{array}{l}\text { GOOD: As expected, they were able to } \\
\text { show that "c }<5 \text { ", and they were able to } \\
\text { show the range. }\end{array}$ & \multirow[t]{2}{*}{ Question: What can be said for $\mathrm{c}$ if $\mathrm{c}+\mathrm{d}=10$ and $\mathrm{c}$ is smaller than $\mathrm{d}$ ? } \\
\hline & $\begin{array}{l}\text { MEDIOCRE: They stated that } \mathrm{c}=5 \text { but } \\
\text { they were unable to carry out further } \\
\text { operations. }\end{array}$ & \\
\hline Student & Given " $4 \mathrm{c}+3 \mathrm{f}$ " for " $\mathrm{c}=2$ and $\mathrm{f}=5$ ", & \multirow{2}{*}{$\begin{array}{l}\text { This means that the student was not able to understand that the } \\
\text { variable no longer needed to be written after the value of the variable } \\
\text { was known. }\end{array}$} \\
\hline Mistakes & $\begin{array}{l}\text { The student wrote that } 4 \times \mathrm{c}(2)=8 \text { and } \\
3 \times \mathrm{f}(5)=15 . \text { Then he gave the answer } 8 \\
+15=23 \text {. }\end{array}$ & \\
\hline
\end{tabular}

For the variable to be a known value, the variable must be assigned a value and this known value must be replaced for the variable. By drawing arrows, the students pointed out that they were considering replacing the known value for the variable. Moreover, the students thought in a multifaceted way. For example, they understood that $7 \mathrm{u}$ meant 7 $\times \mathrm{u}$, and that when a value was assigned to $\mathrm{u}$, it had to be multiplied by 7 .

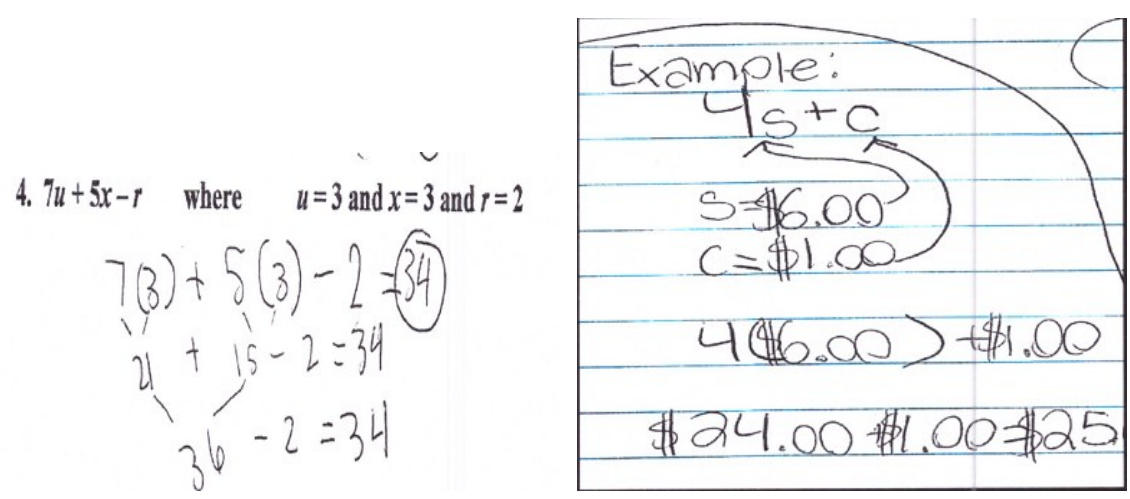

Figure 3. Interpretation of Known Values as Variables

This study belonging to a student who was in the good category shows that he interpreted variables as known values because he gave values for each variable. Moreover, written tips such as drawing arrows or deleting the variable and immediately replacing it with a quantity show that it helps to learn how to replace a variable with a known value.

When a good student noticed that the result was constantly changing for different values of variables, he made an 
effort to calculate the values of the variables.

During the interview, the following question was asked: " $a+b=b$. Is this always true?"

30H: It may not always be true.

T: Why?

32H: "a" may not always be zero.

33T: Well, what if $\mathrm{b}=0$ ?

$34 \mathrm{H}$ : Wait a minute. If $\mathrm{b}$ is zero and a is also zero, then it is possible.

In this question, a student with good performance explained a mathematical situation. When explaining this, the student thought of all the situations in which variables could assume different values. It is seen that he benefited from his prior knowledge while reaching a solution. It can be said that he performed the "building-with" epistemic action to do that. The answer given by a student with moderate performance was different.

39M: If I make "a" 0, "b” also takes a numerical value accordingly.

Unlike a student with good performance, a student with moderate performance was able to think of variables as quantities different from each other. Nevertheless, he was not able to go beyond that.

At this point, the students established relational thinking by establishing a connection between variables as known values and variables as unknown values, understanding the relationship between the ideas of these variables.

Table 6. The Teaching Process of a Variable as Unknown Value

\begin{tabular}{|c|c|c|}
\hline Goals & Development Progressions & Instructional task \\
\hline \multirow[t]{3}{*}{$\begin{array}{l}\text { Variable } \\
\text { as } \\
\text { unknown } \\
\text { value }\end{array}$} & $\begin{array}{l}\text { R: They performed a series of arithmetic } \\
\text { operations during the activity (Think of a number, } \\
\text { add } 3 \text { to it, multiply the result by } 2 \text {, subtract } 4 \text { from } \\
\text { it, divide it by } 2 \text {, subtract the number you thought } \\
\text { from it. Is the result } 1 \text { ?) } \\
\text { They were able to perform the arithmetic } \\
\text { operations in the order given }\end{array}$ & $\begin{array}{l}\text { A4: In the "think of a number" activity, a situation } \\
\text { is portrayed, which included a closed box and an } \\
\text { unknown number of objects, to make it clear that } \\
\text { the variable had an unknown numerical value. } \\
\text { After that, the operations carried out within the } \\
\text { activity ensure that it is understood by the students } \\
\text { that a variable can enter the operations and that } \\
\text { results can be obtained by isolating it. }\end{array}$ \\
\hline & $\begin{array}{l}\text { B: They were able to visually model the } 4 \\
\text { operations they performed. }\end{array}$ & $\begin{array}{l}\text { They were asked to visually model the operations } \\
\text { they performed arithmetically. }\end{array}$ \\
\hline & $\begin{array}{l}\text { They were able to create a visual model for A4. } \\
\text { C: They were able to write an algebraic expression } \\
\text { using visual and arithmetic expressions for A4. } \\
\text { They were able to perform four basic arithmetic } \\
\text { operations with variables. }\end{array}$ & $\begin{array}{l}\text { It was asked that the visual model be modeled } \\
\text { algebraically. It was expected that four basic } \\
\text { arithmetic operations were performed by using } \\
\text { variables. }\end{array}$ \\
\hline \multirow[t]{2}{*}{ CDTA } & $\begin{array}{l}\text { GOOD: as expected, they were able to determine } \\
\text { the number " } 2 \text {," which was the critical point, and } \\
\text { interpret the increase. }\end{array}$ & \multirow[t]{2}{*}{$\begin{array}{l}\text { Which one is greater, } 2 n \text { or } n+2 \text { ? Why? Please } \\
\text { explain. }\end{array}$} \\
\hline & $\begin{array}{l}\text { MEDIOCRE: The students stated that the } \\
\text { multiplication would increase more quickly, but } \\
\text { were unable to specify what values would apply to } \\
\text { "n". }\end{array}$ & \\
\hline $\begin{array}{l}\text { Student } \\
\text { Mistakes }\end{array}$ & $\begin{array}{l}\text { The equation was } 21=7 \mathrm{u} \text {. The student subtracted } \\
7 \text { from both. } \\
\mathrm{u}=14\end{array}$ & $\begin{array}{l}\text { This means that the student was trying to solve it } \\
\text { for the unknown variable, but he was using the } \\
\text { wrong operation and must understand that } 7 \mathrm{u} \\
\text { means } 7 \times \mathrm{u} \text {. }\end{array}$ \\
\hline
\end{tabular}


The teacher explained to the student that a variable was not known unless the value of the variable was specified. In other words, if the students had to solve the variable, they realized it was an "unknown variable." If they did not need to solve it for the variable, if the value for the variable was provided, the variable was interpreted as a "known variable." They were encouraged by the procedures for simple expressions. Attention was paid to solve more examples that were similar. Word problems were asked, in particular, and when finding the solution, they were asked both to write the expression algebraically and to solve it. The purpose was to allow the students to understand the relationship between the solution and the algebraic expression.

For the students, it was interesting that the number that they had thought of could be found as a result of some operations. Their desire to understand whether it had a trick and how it worked enabled them to enter the learning process. The transitions between arithmetic, visual and algebraic representations were carried out together with the class. We can summarize that in a table.

Table 7. The "Thought of a Number" Activity

\begin{tabular}{|c|c|c|}
\hline Steps & Visualization of the Result & Algebraic Expression \\
\hline Think of a number & & $\mathrm{x}$ \\
\hline $\begin{array}{l}\text { Add } 3 \text { to the number you } \\
\text { thought of }\end{array}$ & & $x+3$ \\
\hline Multiply it by two & & $(x+3) \times 2=2 x+6$ \\
\hline Subtract 4 from it & & $2 x+6-4=2 x+2$ \\
\hline Divide it by two & & $\frac{2 x+2}{2}=x+1$ \\
\hline $\begin{array}{l}\text { Subtract from it the } \\
\text { number you first thought } \\
\text { of }\end{array}$ & 0 & $x+1-x=1$ \\
\hline Now the result is easy... & Here's the result, $1 !$ & 1 \\
\hline
\end{tabular}

Instructions such as the following were given: "Now create your own tricks. Experiment with your friend. Show these experiments in a table." When playing this game, they unwittingly practiced manipulating variables.

During the interview process, variables as both known and unknown values were questioned. In the question about "exam scores," the question stem was given in a context that the students were accustomed to. Question: When calculating a student's course grade (M) in a course, the formula is used if his grades from the 3 exams he took were $\mathrm{A}, \mathrm{B}$, and $\mathrm{C}$.

$$
M=\frac{A+B+C}{3}
$$

Accordingly: If $\mathrm{A}=80, \mathrm{~B}=40$, and $\mathrm{C}=20, \mathrm{M}=$ ? If $\mathrm{A}=20, \mathrm{~B}=40$, and $\mathrm{C}=80$, would the course grade change?

81T: How did you find 140 ? 
82H: By summing up three exams.

$83 \mathrm{H}$ : Why did you divide it by three?

$84 \mathrm{H}$ : Because he took three exams.

85T: Now, can we answer the next question?

$86 \mathrm{H}$ : It does not change.

87T: Why?

$88 \mathrm{H}$ : This is because we are doing the same thing again.

89T: Like what?

90H: "A" and "C" were swapped. When you add them, it becomes 140. We would again divide it by 3.

In the process of solving this problem, the student calculated an average based on his previous knowledge, without taking into account the formula and the algebraic expression for the first part of the question. However, the situation for the second part of the question differs slightly. As in dialogue $90 \mathrm{H}$, he stated that he used the numerical values for the variables " $A$ " and " $C$ ", and even said that the numerical values of the two variables were swapped. In this regard, he generated solutions that required the addition of similar information. This indicates that the concept of variable was noticed in the epistemic action of "building-with." The student with moderate performance also solved the question in a similar way. The student understood the mathematical situation that he encountered, but could not use a mathematical language of algebra to explain this situation. Instead, he took advantage of a method of arithmetic solution. That is, he employed numbers during the process. He did not use the variables.

Considering how the students with good performance performed abstraction about the concept of variable, it was generally observed that they exhibited behaviors indicative of the epistemic action of "building-with." It was found that the good students, in particular, developed a new mathematical language when expressing the rule of the pattern and exhibited the epistemic action of "construction."

The questions were chosen to be context-based to create opportunities for the students to perform operations and develop different solutions. In terms of problem solving, it is understood that the students with good performance sometimes tried to classify the questions as arithmetic or algebraic (which requires the use and manipulation of symbols). Especially the first solution strategies of the good students were algebraic. However, they tried to continue the solution arithmetically in cases of difficulty.

\subsection{Findings on Quantitative Data}

In this study, there were two reasons for administering the CDTA. The first was to determine the prior knowledge of the students about the concept of variable when creating the learning trajectory. The second was to statistically compare the students to determine how the learning activities affected the students' understanding of the concept of variable. Based on the result of the paired-samples t-test conducted to determine whether there was a difference between the mean scores on CDTA a significant difference was found between the mean CDTA scores before the implementation $\left(\right.$ Mean $_{\text {CDTA }}$ pretest $\left.=9.32\right)$ and those after the implementation $\left(\right.$ Mean $_{\text {CDTA }}$ posttest $\left.=11.89\right)\left(\mathrm{t}_{28}=\right.$ $-6.72, \mathrm{p}<.05)$.

Table 8. Paired-Samples t-test Results Based on the 6th Grade Students' CDTA Scores

\begin{tabular}{ccccccc}
\hline Tests & $\mathrm{n}$ & $\mathrm{M}$ & $\mathrm{SD}$ & $d f$ & $t$ & $p$ \\
\hline CDTA pretest & 29 & 9.32 & 5.25 & 28 & -6.72 & 0.000 \\
CDTA posttest & 29 & 11.89 & 5.60 & & & \\
\hline
\end{tabular}

The effect size calculated as a result of the t-test $(\mathrm{d}=.51)$ indicates that this difference was moderate. This shows that the hypothetical learning trajectory administered to the 6th-grade level had a positive impact on the development of the students' ability to identify algebra concepts.

\section{Discussion}

Hypothetical learning trajectories can associate theoretical perspectives from current research on mathematical content as well as experimental evidence on how students learn mathematics. 
In this study, the learning trajectory was shaped based on the students' and the teacher's interpretations of the concept of variable. In this respect, the learning trajectory had practical outcomes for the students' learning and mental development. A hypothetical learning trajectory was designed to make the students' abstract thoughts more visible and understandable. In this process, it was desired to eliminate the handicaps of the students who encountered the concept of variable for the first time. In the interviews, the students were unable to demonstrate satisfactory abstraction regarding the concept of variable, especially regarding the use of variables. The students with good performance were able to achieve this state of abstraction. In this regard, the encouraging effect of hypothetical learning trajectories on the abstraction process of students should not be underestimated.

The t-test findings regarding the students' use of literal symbols show that the learning trajectory contributed positively to the teaching of variables.

One of the critical questions about learning trajectories in algebra is where to start. Although the answer depends on local conditions, the most critical phase has been considered particularly to be the transition between arithmetic and algebra (Kieran, 2018). For this reason, the transition between arithmetic and algebra requires special attention that is only possible by the level of micro-conceptual development (Baroody, 2009) warranted by detailed learning trajectories for relevant concepts. The learning trajectory for introduction to algebra includes the sorts of thinking that occur in the process of understanding a variable.

In the "thought of a number" activity, the students used visual representations, then arithmetic representations, and finally algebraic representations with letters, which was found to help them differentiate between variables as unknown and known values. Research has shown that working with visual, verbal and symbolic models lead to positive outcomes in terms of helping students recognize generalizations in relations regardless of objects (Warren, 2006). The relevant finding in the present study supports the literature.

Research over the past three decades has shown that each use of variables is linked to specific epistemological and didactic barriers (Warren, Trigueros, \& Ursini, 2016). The starting point of algebra needs to be the use of only a specific type of variable. The relationships between different uses of variables prevent the possibility of flexibility and restrain the understanding of algebra (Kieran, 2006). Wille (2008), however, pointed out that when students experience different aspects of variables, the versatility of their thinking about variables is improved. In this study, uses of variables as known and unknown values were presented with a clear distinction for the students. The conditions for this distinction were determined by discussing them in relation to the classroom environment. In the learning trajectory, the students developed the idea that a variable disappears when it is replaced with a number to distinguish between variables as known and unknown values. In the process, the interpretation of the expression "7u" as " $7 \times$ u" emerged from the students' discussions about terms, coefficients, algebraic expressions and variable concepts. Similar to Kieran's (1989) findings, the findings of the present study show that the students perceived variables as unknown values as their levels of thinking were enhanced, and were able to take the first step to understand the systematic structure of an equation. Moreover, the students' written tips such as drawing arrows or deleting the variable show that it helps to learn how to replace a variable with a known value.

The students with good performance used richer strategies when working on variables, and the fact that they could develop a short strategy to determine the rule of the pattern is an indication of this. It was seen that they were able to develop their own mathematical language and explain it in order to identify the rule of the pattern in the subsequent discussions. The distinctive mathematical language they developed is an indicator of their epistemic action of "construction." This is proof that they were clearly observing abstraction in the use of algebraic expressions. The role of the teacher and the class discussions played an important role in the language process developed during this abstraction phase. However, this study shows that the development of thinking on variables is embedded in the progression of the concept of variable as a changing quantity. Blanton (2008) and Blanton and Kaput (2003) proposed to teach algebra by changing known, unknown and changing objects or groups. The findings of this study suggest teaching processes, expressions and equations, starting with the concept of variable as a label and continuing with the concept of variable as a changing quantity, variable as a known value, and variable as an unknown value.

Finally, studies are needed to understand how children perceive variables and use variable representations in other fields of mathematics (Blanton et al., 2011). Moreover, similar studies can be conducted for the use of variables in mathematical equations and for the understanding and interpretation of variables when solving equations. 


\section{References}

Abdi, H. (2007). The Kendall rank correlation coefficient. Encyclopedia of Measurement and Statistics. Sage, Thousand Oaks, CA, 508-510.

Baroody, A. J., Baroody, A., Lait, M., \& Li, X. (2009). Young Children's Understanding and Application of Subtraction-Related Principles. Mathematical Thinking and Learning, 1\&2(11), 41-60. https://doi.org/10.1080/10986060802583873

Blanton, M. L. (2008). Algebra and the elementary classroom: Transforming thinking, transforming practice. Heinemann Educational Books.

Blanton, M. L., \& Kaput, J. J. (2003). Developing elementary teachers': "Algebra eyes and ears". Teaching children mathematics, $10(2), 70-78$.

Blanton, M., Brizuela, B. M., Gardiner, A. M., Sawrey, K., \& Newman-Owens, A. (2015). A learning trajectory in 6-year-olds' thinking about generalizing functional relationships. Journal for Research in Mathematics Education, 46(5), 511-558. https://doi.org/10.5951/jresematheduc.46.5.0511

Blanton, M., Levi, L., Crites, T., Dougherty, B., \& Zbiek, R. M. (2011). Developing Essential Understanding of Algebraic Thinking for Teaching Mathematics in Grades 3-5. Series in Essential Understandings. National Council of Teachers of Mathematics. 1906 Association Drive, Reston, VA 20191-1502.

Brizuela, B. M., Blanton, M., Sawrey, K., Newman-Owens, A., \& Murphy Gardiner, A. (2015). Children's use of variables and variable notation to represent their algebraic ideas. Mathematical Thinking and Learning, 17(1), 34-63. https://doi.org/10.1080/10986065.2015.981939

Brown, M., Hart, K., \& Kuchemann, D. (1985). Chelsea diagnostic mathematics tests and teacher's guide. Windsor: NFER-NELSON Publishing Company Ltd.

Can, A. (2013). SPSS ile bilimsel araştırma sürecinde nicel veri analizi. Ankara: Pegem A. https://doi.org/10.14527/9786053644484

Celik, D., \& Gunes, G. (2013). Different Grade Students' Use and Interpretation of Literal Symbols. Educational Sciences: Theory and Practice, 13(2), 1168-1175.

Ç1kla, O. A. (2004). The effects of multiple representations-based instruction on seventh grade students' algebra performance, attitude toward mathematics, and representation preference. Unpublished doctoral dissertation, Middle East Technical University, Ankara.

Clements, D. H., \& Sarama, J. (2004). Learning trajectories in mathematics education. Mathematical thinking and learning, 6(2), 81-89. https://doi.org/10.1207/s15327833mt10602_1

Clements, D. H., \& Sarama, J. (2009). Learning trajectories in early mathematics - Sequences of acquisition and teaching. Encyclopedia of Language and Literacy Development (pp. 1-6). London, ON: Canadian Language and Literacy Research Network. Retrieved from http://literacyencyclopedia.ca/pdfs/topic.php?topId=270

Confrey, J., \& Maloney, A. (2010). Defining and Implementing Learning Trajectories as Research Tools. Paper presented at the Research Presession of the Annual Meeting of the National Council of Teachers of Mathematics, San Diego, CA.

Dede, Y., \& Argün, Z. (2003). Cebir, öğrencilere niçin zor gelmektedir? Hacettepe Üniversitesi Ĕ̌itim Fakültesi Dergisi, 24(24), 180-185.

Dreyfus, T., \& Tsamir, P. (2004). Ben's consolidation of knowledge structures about infinite sets. The Journal of Mathematical Behavior, 23(3), 271-300. https://doi.org/10.1016/j.jmathb.2004.06.002

Drijvers, P., Goddijn, A., \& Kindt, M. (2011). Algebra education: Exploring topics and themes. In Secondary algebra education (pp. 5-26). Brill Sense. https://doi.org/10.1007/978-94-6091-334-1_1

Driscoll, M. (1999). Fostering Algebraic Thinking: A Guide for Teachers, Grades 6-10. Heinemann, 361 Hanover Street, Portsmouth, NH 03801-3912.

Ersoy, Y., \& Erbaş, K. (1998). İlköğretim okullarında cebir öğretimi: Öğrenmede güçlükler ve öğrenci başarıları. Cumhuriyetin, 75, 27-28.

Glesne, C. (2013). Introduction to qualitative research. Ankara, Turkey: Anı Yayınları.

Hart, K. M., Brown, M. L., Kerslake, D. M., Küchemann, D. E., \& Ruddock, G. (1998). Children's understanding of 
mathematics: 11-16. London: Athenaeum Press.

Kieran, C. (1992). The learning and teaching of school algebra. In D. Grouws (Ed.), Handbook of research on mathematics teaching and learning (pp. 390-419). New York: Simon \& Schuster.

Kieran, C. (2018). The early learning of algebra: A structural perspective. In Research issues in the learning and teaching of algebra (pp. 33-56). Routledge. https://doi.org/10.4324/9781315044378-4

Linchevski, L., \& Herscovics, N. (1996). Crossing the cognitive gap between arithmetic and algebra: Operating on the unknown in the context of equations. Educational studies in mathematics, 30(1), 39-65. https://doi.org/10.1007/BF00163752

MacGregor, M., \& Stacey, K. (1997). Students' understanding of Algebraic Notation: 11-15. Educational studies in mathematics, 33(1), 1-19. https://doi.org/10.1163/9789087901509_006

Marshall, C., \& Rossman, G. B. (2014). Designing qualitative research. Sage publications.

Maxwell, J. A. (2005). Designing a qualitative study. The SAGE handbook of applied social research methods, 2, 214-253. https://doi.org/10.4135/9781483348858.n7

MEB [Milli Eğitim Bakanlığı]. (2017). Ortaokul matematik dersi 5-8. sinıflar öğretim programı. Ankara: MEB.

Miles, M. B., \& Huberman, M. (1994). Qualitative Data Analysis: A Sourcebook of New Methods (2nd ed.). Beverly Hills, CA: Sage Pulications.

Philipp, R. A. (1992). The many uses of algebraic variables. The Mathematics Teacher, 85(7), 557-561.

Schoenfeld, A. H., \& Arcavi, A. (1988). On the meaning of variable. The mathematics teacher, 81(6), 420-427.

Simon, M. A. (1995). Reconstructing mathematics pedagogy from a constructivist perspective. Journal for Research in Mathematics Education, 26(2), 114-145. https://doi.org/10.2307/749205

Simon, M. A., \& Tzur, R. (2004). Explicating the role of mathematical tasks in conceptual learning: An elaboration of the hypothetical learning trajectory. Mathematical Thinking and Learning, 6(2), 91-104. https://doi.org/10.1207/s15327833mt10602_2

Şimşek, H., \& Yıldırım, A. (2011). Sosyal bilimlerde nitel araştırma yöntemleri. Ankara: Seçkin Yayıncılık.

Soylu, Y. (2008). 7. sınıf öğrencilerinin cebirsel ifadeleri ve harf sembollerini (değişkenleri) yorumlamaları ve bu yorumlamada yapılan hatalar. Selçuk Üniversitesi Ahmet Keleşoğlu Eğitim Fakültesi Dergisi, 25, 237-248.

Steffe, L. P., \& Thompson, P. W. (2000). Teaching experiment methodology: Underlying principles and essential elements. Handbook of research design in mathematics and science education, 267-306.

Treffers, A. (1987). Three Dimensions. A Model of Goal and Theory Description in Mathematics Instruction - the Wiskobas Project. Dordrecht: Reidel Publishing Company. https://doi.org/10.1007/978-94-009-3707-9

Warren, E. (2006). Teacher actions that assist young students write generalizations in words and in symbols. In J. Novotna et al. (Ed.), Proceedings of the 30 th Conference of the International Group for the Psychology of Mathematics Education (Vol. 5, pp. 377-384).

Warren, E., Trigueros, M., \& Ursini, S. (2016). Research on the learning and teaching of algebra. In Gutiérrez Á., Leder G. C., \& Boero P. (Eds.), The Second Handbook of Research on the Psychology of Mathematics Education. Sense Publishers, Rotterdam. https://doi.org/10.1007/978-94-6300-561-6_3

Wille, A. M. (2008). Aspects of the concept of a variable in imaginary dialogues written by students. In O. Figueras, J. Cortina, S. Alatorre, T. Rojano \& A. Sepúlveda (Eds.), Proceedings of the 32nd Conference of the International Group for the Psychology of Mathematics Education (PME32) (vol. 4, pp. 417-424).

Yeşildere, S. (2006). Farkl Matematiksel Güce Sahip İlköğretim 6., 7. ve 8. Sinlf Öğrencilerinin Matematiksel Düşünme ve Bilgiyi Oluşturma Süreçlerinin İncelenmesi. Yayımlanmamış Doktora Tezi, Dokuz Eylül Üniversitesi, İzmir. https://doi.org/10.1501/Egifak_0000000156 